\title{
H19 Opposite Tumor Suppressor
}

National Cancer Institute

\section{Source}

National Cancer Institute. H19 Opposite Tumor Suppressor. NCI Thesaurus. Code

C114311.

H19 opposite tumor suppressor (151 aa, 17 kDa) is encoded by the human HOTS gene.

This protein may play a role in tumor suppression. 